\title{
Effect of Captive Rearing on Meat and Haemolymph Nutritional Characteristics of Snail (Archachatina marginata swainson)
}

\section{DIAKA, IE; *KEHINDE, AS; ${ }^{2}$ BABATUNDE, OO; ${ }^{1}$ ADEBISI-FAGBOHUNGBE, TA; ${ }^{1}$ ABULDULAZEEZ, FA; ${ }^{1}$ GANIYU, OA; ${ }^{3}$ OYEDIRAN, OB; ${ }^{1}$ UDAGHE, OM}

\author{
${ }^{*}$ Department of Wildlife and Ecotourism, Forestry Research Institute of Nigeria. \\ ${ }^{2}$ Department of Wood and Paper Technology, Federal College of Forestry, Jericho, Ibadan, Oyo State, Nigeria \\ ${ }^{3}$ Federal College of Wildlife Management, New Bussa, Nigeria \\ *Corresponding Author Email: Sollybee2012@gmail.com
}

\begin{abstract}
An experiment was conducted to investigate and compare the impact of treatment, which is the source of snail (wild and captive reared) on the proximate and mineral composition ( $\mathrm{Na}, \mathrm{K}, \mathrm{Ca}, \mathrm{Mg}, \mathrm{P}, \mathrm{Fe}$ and $\mathrm{Mn}$ ) of the meat and haemolymph of African land snails (Archachatina marginata). Ninety (90) adult snails $(250.00+0.5 \mathrm{~g})$ were randomly distributed into two (2) treatments, each of three replicates, (15 snails per replicate), in a Complete Randomized Design. Samples of meat and haemolymph collected using standard procedures were subsequently analyzed for their nutritional qualities, using standard chemical analytical procedures. All data collected were statistically analyzed using ANOVA, while significant variation were separated with Duncan Multiple Range Test of the same package. The proximate composition of the meat revealed higher $(\mathrm{P}>0.05)$ DM $(26.00 \%)$, Ether extract $(2.17 \%)$ and NFE $(3.57 \%)$ in SC, while there was a non-significant variation $(\mathrm{P}<0.05)$ in most proximate factors for haemolymph, except NFE (4.27\%), which was higher ( $\mathrm{P}>0.05)$ in SW. The mineral profiling of the meat revealed elevated (PP>0.05) levels of Fee $(22.30 \mathrm{mg} / \mathrm{kg}$ ) and $\mathrm{Mn}(4.79 \mathrm{mg} / \mathrm{kg})$ of SC, the haemolymph recorded improved levels $(\mathrm{P}>0.05)$ for all mineral elements in SC. In conclusion, the captive rearing of snail had improved impact on the nutritional qualities of SC.
\end{abstract}

\section{DOI:https://dx.doi.org/10.4314/jasem.v25i9.20}

Copyright: Copyright $\odot 2021$ Odiaka et al. This is an open access article distributed under the Creative Commons Attribution License (CCL), which permits unrestricted use, distribution, and reproduction in any medium, provided the original work is properly cited.

Dates: Received: 09 May 2021; Revised: 12 August 2021; Accepted: 12 September 2021

Keywords: Haemolymph, meat, snail, proximate, mineral, nutritional qualities

The supply of snail meat is mainly from the wild, especially in the humid forest of Southern part of Nigeria (Kehinde et al., 2020). The snail breeds (Archachatina marginata, Achatina achatina, Achatina fulica and Limicolaria species (Omole, 2002) are commonly picked by gatherers, immediately after rains (Hamzat and Longe, 2002) in Nigeria. The supply of snail from the wild cannot guarantee all year round availability, hence the need for domestication (Okonkwo et al., 2007). This study tried to explore the potentials of the most abundant species of snail (Archachatina marginata) which is consumed for its diverse nutritional and cultural importance, Omole (2002), stated that all parts of snail are useful. Its shell is a good source of Calcium carbonate and its concentration varies with age (Ademola et al., 2016), location and climate. It can be adopted for the replacement of bone meal and oyster shell in poultry diets, after thorough treatment against microbes (Popoola and Omole, 2019). The visceral mass, which accounts for about $35 \%$ of snails carcass can be dried and utilized as a source of organic soil mineralization (Ebenso, 2003). The liquid or fluid drained from snails (haemolymph) is used as healing agents and consumed to suppress blood pressure and treatments of blood related ailments (Alabi et al., 2015). This fluid is bluish in colour, which is impacted by the presence of copper (Abiona et al., 2007). The foot, which is the edible part of snail (Lin et al., 2006), accounts for 38 - $45 \%$ of the carcass yield, it is eaten by man and regarded as delicacy (Odabo, 2000) and cherished by all classes of human population due to its tender nature and its richness in balanced amino acid profile (Popoola, 2000). Snail meat has been widely adopted in traditional medicine, for the treatment of Osteoporosis, anaemia and deficiencies of calcium, phosphorus and magnesium (Kehinde, 2009). Snail meat consumption is particularly recommended for people suffering from hypertension, due to its low level of sodium, which has been widely implicated in muscle paralysis. There have been perception among stakeholders in snail value chain that captive rearing may affect the benefits derivable from snail products, thus necessitating the evaluation of the nutritional properties of snail meat and haemolymph from snail collected from the wild and those that were captive 
reared. This will provide empirical bases to make an informed statement on the effects of captive rearing of snail on its nutritional attributes.

\section{MATERIALS AND METHODS}

Sources of Experimental Snails: The snails were sourced from the experimental plots of the Forestry Research Institute of Nigeria at Onigambari of Oluyole Local Government Area of Oyo State and the snail domestication centre of the Institute. All the snails adopted for the trial had an average weight of $(250.00 \pm 0.50 \mathrm{~g})$.

Snail Treatment (Detoxification): The snails were housed in experimental cages, and there were two treatments (snails from the wild and those that are captive reared). They were fed with concentrate diets for three days, to egest unwanted ingested feedstuffs and chemicals from their gut, for purity of samples collected (Akinnusi et al., 2019).

Experimental Treatments: There were two treatments, which represented, snails from the wild (SW) and snails in captivity (SC). Forty-five snails each were used per treatment of three replicates.

Carcass Evisceration: Established standard of evisceration of Omole (2002) was adopted to remove the body parts from the shell, followed by the determination of the carcass yield. This method enabled the separation of snail body parts into shell, visceral mass and foot.

Meat and Haemolymph Sample Collection: All snails were cleaned, to avoid sample contamination. Each shell was carefully opened at the pointed end of the shell for the collection of haemolymph $(5 \mathrm{ml}) .5 \mathrm{ml}$ of haemolymph and meat $(5 \mathrm{~g})$ per replicate by the procedure of Omole (2002).

Proximate Constituents Determination for Meat and Haemolymph of Snail: The meat and haemolymph proximate composition were determined by the method of A.O.A.C (1995), this elicited, dry matter, crude protein, crude fiber, ether extract, ash and NFE.

Mineral Composition Determination for Meat and Haemolymph of Snail: The levels of $\mathrm{Na}, \mathrm{K}, \mathrm{Ca}, \mathrm{Mg}, \mathrm{P}$, $\mathrm{Fe}$ and $\mathrm{Mn}$ in the meat and haemolymph of Archachatina marginata were determined using the method of Sam et al., (2019).

Statistical Analysis: Data collected from the two treatments (snails from the wild (SW) and snails in captivity (SC)) were analysed using one way Analysis of Variance (ANOVA), while significant means were separated using Duncan Multiple Range Test (1955).

\section{RESULTS AND DISCUSSION}

Table 1 elicited the proximate composition of snail meat from two sources, snail from the wild (SW) and captive reared snails (SC). Meat from captive reared snail is significantly higher $(\mathrm{P}>0.05)$ in crude fat $(2.17 \%)$, NFE $(3.57 \%)$ and DM (26.00\%). It shows that snails reared in captivity had improved levels of all the proximate components, with levels within ranges obtained by (Ajibola et al., 2018, Akinnusi et al., 2019 and Ejidike and Ojekunle, 2019). The outstanding $(\mathrm{P}>0.05)$ levels of DM, NFE and crude protein could be attributed to more organized feeding in captivity, associated with improved intake of nutrients from forages and supplementary concentrate. Omole, (2002) and Hamzat and Longe (2002) had obtained better performance in snails in captivity, when they obtained higher dressing percentage ( $40-$ $45 \%$ ), while snails from the wild always recorded values lower from $40 \%$, as a result of lower rate of dry matter bio-accumulation due to poor dietary intake, exposure to unfavourable weather condition and their unrestricted movement. The nutritional requirements of Archachatina marginata determined by Omole (2002) revealed a higher nutritional requirement for protein $(30 \%)$ by adult snails, this was attributed to their better performance in captivity, coupled with good housing system and restricted movement, resulting in better food utilization.

Table 1: Proximate composition of the meat of Archachatina marginata from the wild and captive reared

\begin{tabular}{llll}
\hline $\begin{array}{l}\text { Proximate } \\
\text { composition (\%) }\end{array}$ & SW & SC & SEM \pm \\
\hline Crude protein & 17.14 & 17.78 & 0.50 \\
Crude fat & $1.57^{\mathrm{b}}$ & $2.17^{\mathrm{a}}$ & 0.40 \\
Crude fiber & 0.17 & 0.27 & 0.10 \\
Ash & 1.90 & 2.30 & 0.20 \\
NFE & $2.95^{\mathrm{b}}$ & $3.57^{\mathrm{a}}$ & 0.40 \\
DM & $23.74^{\mathrm{b}}$ & $26.00^{\mathrm{a}}$ & 1.00 \\
\hline
\end{tabular}

a.b Means with different superscripts on the same row are significantly $(P>0.05)$ different; $S W$ : Snails sourced from the wild; SC: Snails Captive reared

Table 2: Proximate composition of haemolymph of wild and captive reared snails (Archachatina marginata)

$\begin{array}{llll}\text { Proximate } & \text { SW } & \text { SC } & \text { SEM } \pm\end{array}$
composition (\%)

$\begin{array}{llll}\text { Crude protein } & 4.01 & 4.61 & 1.00\end{array}$

$\begin{array}{llll}\text { Crude fat } & 0.02 & 0.03 & 0.15\end{array}$

$\begin{array}{llll}\text { Crude fiber } & 0.00 & 0.00 & 0.00\end{array}$

$\begin{array}{lll}\text { Ash } & 0.73 \quad 0.85 & 0.30\end{array}$

NFE $\quad 4.27^{\mathrm{a}} \quad 3.90^{\mathrm{b}} \quad 0.50$

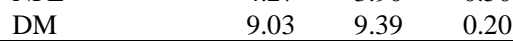

a.b Means with different superscripts on the same row are significantly $(P>0.05)$ different; $S W$ : Treatment with snail sourced from the wild; SC: Treatment with snails from captivity

Table 3: Mineral constituent of snail meat from the wild and those that were captive reared Treatment 


\begin{tabular}{llll}
\hline $\begin{array}{l}\text { Mineral } \\
\text { composition } \\
(\mathrm{mg} / \mathrm{kg})\end{array}$ & SW & SC & SEM \pm \\
\hline $\mathrm{Na}(\%)$ & 0.70 & 0.08 & 0.02 \\
$\mathrm{~K}(\%)$ & 0.21 & 0.22 & 0.02 \\
$\mathrm{Ca}(\%)$ & 0.11 & 0.12 & 0.03 \\
$\mathrm{Mg}(\%)$ & 0.02 & 0.02 & 0.01 \\
$\mathrm{P}(\%)$ & 0.02 & 0.03 & 0.02 \\
$\mathrm{Fe}(\%)$ & $18.10^{\mathrm{b}}$ & $22.30^{\mathrm{a}}$ & 1.01 \\
$\mathrm{Mn}(\%)$ & $3.39^{\mathrm{b}}$ & $4.79^{\mathrm{a}}$ & 0.50 \\
\hline
\end{tabular}

a.b Means with different superscripts in a row are significantly $(\mathrm{P}>0.05)$ different

Table 4: Mineral composition of the haemolymph of snails from the wild and captive reared Treatment

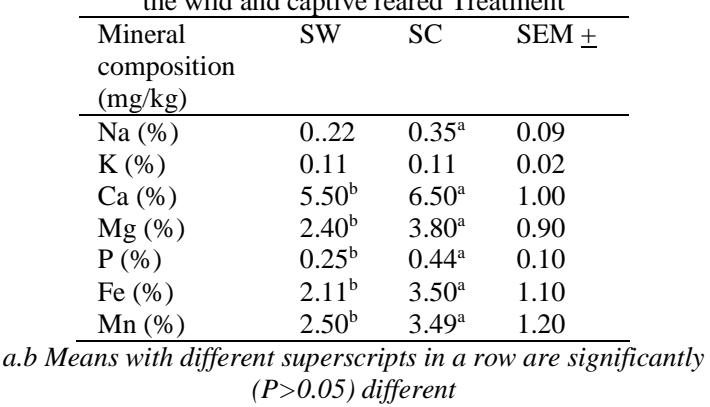

Table 2 had the proximate values of the haemolymph of snail from the wild and captivity. All values compared, except the NFE, which was higher in SW $(4.27 \mathrm{~g} / 100 \mathrm{ml})$. The values obtained implied that treatments were favourable to the proper functioning of the visceral organs, such as the organs of digestion and excretion. The result of this trial has corroborated the values of the proximate composition of the meat and haemolymph obtained by (Ademolu et al., 2019). It was further revealed that meat of snails had more nutrients than the haemolymph, the same trend was obtained by Babalola and Akinsoyinu, (2018) and Akinnusi et al., 2019). The mineral composition of the meat and haemolymph was determined on tables 3 and 4 respectively, revealed the levels of $\mathrm{Na}, \mathrm{K}, \mathrm{Ca}, \mathrm{Mg}$, $\mathrm{P}, \mathrm{Fe}$ and $\mathrm{Mn}$ in snail meat in SW and SC. It was observed that the levels of Fe $(22.30 \mathrm{mg} / \mathrm{kg})$ and $\mathrm{Mn}$ $(4.79 \mathrm{mg} / \mathrm{kg})$ were higher in the meat of SC, with the same trend for all minerals in the haemolymph. The study further revealed that all mineral contents of the haemolymph were higher $(\mathrm{P}>0.05)$ in $\mathrm{SC}$.

Regular feeding of snails in captivity is an important factor for consideration in the bio-accumulation of nutrients (Kehinde, 2009). This reflected in the improved level of iron in snail meat from SC, a mineral element that is vital (Popoola, 2020) and had been variously reported to promote oxidative phosphorylation (Adegoke et al., 2010) and helps in prevention of anaemia (Eboua et al., 2010). It is a common practice in traditional medicine, for pregnant women in Africa and people suffering from blood related ailments, to drink unadulttrated raw snail haemolymph to supply nutrients such as $\mathrm{Na}, \mathrm{K}, \mathrm{Ca}$, $\mathrm{Mg}, \mathrm{P}, \mathrm{Fe}$, and $\mathrm{Mn}$; which are important for the proper functioning of the human body systems (Hamzat and Loonge, 2002). It was noted in this trial that SC recorded higher $(\mathrm{P}>0.05)$ values of mineral salts, which could be due to better plane of nutrition in snails reared in a confined environment and suggested that captive rearing with good nutrition helps in better bioaccumulation of mineral salt due to improved feeding and provision of condusive environment, unlike those in the wild that only feed on forage, which are of lower nutritive value; consequently the snails in SW always recorded lower dressing percentage based on the reports of various trials by (Hamzat and Longe, 2002; Omole, 2002 and Kehinde, 2009).

Conclusion: The outcomes of this trial have shown that snails in captivity recorded higher levels of mineral elements and proximate components than snails from the wild. It is therefore suggested that farmers and research institutes should intensify on snail rearing to improve human nutrition, income generation and employment opportunities.

\section{REFERENCES}

AOAC (1995): Official methods of analysis, $18^{\text {th }}$ edition Association of Official Analytical Chemists, Washington D.C. Pp 1141.

Adegoke AA, Adebayo-Tayo CB, Inyang UC, Aiyegoro AO and Komolafe, OA (2010): Snails as meat source: Epidemiological and nutritive perspective. J. Microb. Antimicrobial 2(1): $1-5$

Ademolu KO, Olaniyi, P, Ebenso, I and Idowu, AB (2016): Morphometrics and mineral composition of shell whorls in three species of Giant African Land Snails from Abeokuta, Nigeria. Ruthenica 26(3 and 4): $164-169$.

Akinnusi FAO, Oni OO and Ademolu, KO (2019): Variation in chemical composition of shell and haemolymph of Giant African land snail (Archachatina marginata), during wet and dry season in Nigeria. Journal of Mollusca Research(5): 31-36

Alabi JO, Fafiolu AO, Ekemezie AAO and Alimba G.G (2015): Absorption and bioaccumulation of heavy metals in African land snail (Archachatina marginata). Bull. Anim. Health. Product. Afr. 63(4): $115-120$

Daibo AB, Dehinbo AJ, Olofintoye LK and Falode OA (2000): Occurrence and distribution of Rhabditida: Rhabditidae) in African Giant Snails 
in Southwestern Nigeria. Heminthologia 37(4): $233-235$.

Duncan DB (1995): Multiple Range and Multiple F Test, Biometrics, 11: $1-42$

Ebenso IE (2003): Dietary calcium supplement for edible tropical land snail in Niger Delta, Nigeria. J. Livestock. Rural Develop. 15(5): $12-22$

Eboua, NW, Eric, FE, Ernest, K, Bodji, NC and Brou, C. (2010): Impact of the insecticide endosulfan on growth of the African Giant Land Snail (Archachatina marginata). Afr. J. Tech. 4(10): $685-690$.

Hamzat RA and Longe, OG (2002): Performance characteristics of African Giant Land Snail (Archachatina marginata), fed fresh kola testa as sole ingredient. Proceedings of the $28^{\text {th }}$ Annual Conference of Nigeria Society for Animal Production. Pp $1174-176$

Kehinde AS (2009): Utilization of cassava (Manihot esculenta crantz) by-products by African Land Snail (Archachatina marginata swanson). A Ph. D Thesis submitted to the Department of Animal Science, University of Ibadan, Nigeria. P 146

Kehinde AS, Babatunde TO and Kehinde, O.J (2020): Growth performance, qualitative and economic evaluation of snails (Archachatina marginata) fed cassava byproducts. Pacific J. Sci. Tech. 21 (1) $253-259$.
Lin E, Enobukhere V and Ilechie I (2006): Bioaccumulation of heavy metals $(\mathrm{Cu}, \mathrm{Zn}$ and $\mathrm{Fe}$ ) in fresh water snail (Pila ovate), from Ikpoba River of Southern Nigeria. J. Aquuatic Sci. 21: 23 -28 .

Okonkwo AC, Isaac LJ, Nkanga, I and Usoro OO (2007): Effect of various feeding regime on performance of snails (Archachatina marginata). Proceedings of the $25^{\text {th }}$ Annual Conference of Nigeria Society for Animal Production (NSAP), Umudike, Nigeria (Pp 314 - 315), March 19 - 23, 2007.

Omole AJ (2002): Nutrients requirements of Africa Land Snails, raised in the tropics. A Ph.D Thesis Submitted at the Department of Animal Science, University of Ibadan, Nigeria. Pp 8

Popoola YA (2020): Performance and cost benefits of snails fed diets containing varying levels of African Yam Bean Meal. J. Molluscom Res. 6: 23 -29 .

Popoola YA and Omole AJ (2019): Unconventional livestock, neglected and under-utilized livestock, micro-livestock and mini-livestock, where does the edible land snail belong. $8^{\text {th }}$ International Conference on Giant African Snail. Pp 72 - 76 .

Sam IM, Essien CA, Christopher GI, and Ebenso IC (2019): Relationship among performance characteristics and confirmation traits in snails (Archachatina marginata) raised in the tropics. $J$. . Res. Vol 5 Pp $37-42$. 